\title{
Biocontrol of Sugar Beet Pathogens Fusarium Wilt by Trichoderma viride Aida H. Afify ${ }^{1}$; Samia M. M. Bayoumy ${ }^{1}$; A. B. B. El-Sayed ${ }^{2}$ and Samar S.A. Elshal. ${ }^{1}$ ${ }^{1}$ Dept. Microbiology, Fac. Agri. Mansoura Univ., Mansoura, Egypt. \\ ${ }^{2}$ Plant Pathology Research Institute, Agricultural Research Center (A.R.C), Giza, Egypt.
}

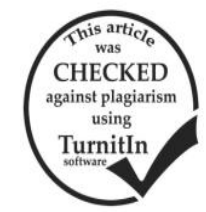

\section{ABSTRACT}

Six fungal strains were isolated from the rhizosphere of sugar beet cultivars in Egypt. Two fungal isolates were effective against three phytopathogenic fungi: Fusarium solani, Fusarium oxysporum and Fusarium dimerum. The two strains were identified and belonged to Trichoderma viride. In vivo the highest percentages of survival plants were $72.5,75$ and $82.5 \%$ by T.viride code No. (2) for the control of F. solani, F. oxysporum and F. dimerum, respectively while more than T.viride code No. (1) . T. viride isolates produced $\mathrm{HCN}$, chitinase and cellulase, but it failed to produce IAA. The usage of $T$. viride as seed treatment reduced the percentage of damping-off of sugar beet under greenhouse conditions. This result shows that these $T$. viride are very effective biocontrol agents and should be harnessed for further biocontrol applications.

Keywords: Trichoderma viride, Biological control, Fusarium wilt, Antagonism.

\section{INTRODUCTION}

Sugar beet (Beta vulgaris L.) is one of the most important sugar crops in many countries of the world. In Egypt, due to the great consumption of sugar, the production of sugar beet must be increased to cover the requirements of sugar which depended sugar cane. Under Egyptian conditions, sugar beet plant attacked by numerous foliar and root diseases, which have been recorded in several reports ( Mosa and El-Kholi, 1996). The most important of soil diseases are damping-off and root-rot disease caused by different pathogens such as Rhizoctonia solani Kuhn, Sclerotium rolfsii Sacc., Phoma (Pelospora) beta Berl. Several species of Fusarium and Phythium were also recorded, i.e. Fusarium solani (Mart) Sacc, F. oxysporum f. sp. conglutinans Wollenw, F. oxysporum Snyder \& Hans, $F$. moniliforium Sacc. and F. meresmoides Corda, Pythium aphanidermatum, $P$. mamillatum Meurfd, $P$. ultimum and $P$. debaryanum Hesse (El-Kholi, 2000). Many rhizospheric microorganisms are known to be equipped with antagonistic potential against soilborne pathogens such as Trichoderma spp. (Chet and Baker, 1981). Trichoderma species is considered biocontrol agents in plant disease control were applied successfully against several plant diseases in commercial agriculture (Howell, 2003). Biocontrol technologies have gained momentum in disease control of crop plants, in recent times as these technologies not only minimize of replace the usages of harmful chemical pesticides but also found to be cheaper and efficient in certain disease control programmers. Yadav et al., 2011 reported that Trichoderm spp. is the most effective as biocontrol against soil-borne diseases. Rhizoctonia, Sclerotium, Fusarium, Pythium and Phophthora caused soil-borne diseases in several crops have been reported. (Cook and Baker, 1983) therefore using biological control such as T.viride which is one the efficient biocontrol have been suggested as being responsible for their bio-control activity which includes mycoparasitism, antibiosis, competition for nutrients and space. These mechanisms are not mutually exclusive and the overall biocontrol activity is due to the synergistic effects of different modes of antagonism (O'Sullivan and O'Gara 1992). Cyanide is a toxic and dreaded chemical. It produced by many rhizobacteria. Some bacteria synthesis it, others excrete it and yet others metabolize it in other to avoid predation and competition. According to Etesami et al., 2009 , production of IAA in plants help to increase root dry weight and thereby increase the plants ability to take up $\mathrm{N}, \mathrm{P}, \mathrm{K}$ compared to untreated control. It caused increase in vegetables especially pepper, cucumber and tomato (Kidoglu et al., 2007). Many microorganisms produce and release lytic enzymes. Polymeric compounds hydrolyze by enzymes including chitinase, proteinase, cellulase, hemicellulase, and DNAase. Nonetheless, microbes that know a preference for colonizing and lysing plant pathogens should be classified as biocontrol agents. This work aims at evaluating the antagonistic effect of some selected fungal isolates against sugar beet pathogens Fusarium wilt and their effects on damping-off and survival sugar beet plants infected with the pathogenic fungi.

\section{MATERIALS AND METHODS}

A total of fifteen fungal isolated from rhizosphere of sugar beet cultivars at different governorates of Egypt and selected six strains for it according to differences between growth on PDA medium during isolation and incubation. These six fungal strains were screening to controlling Fusarium wilt fungi by in vitro antagonism. Pathogens:

Fusarium solani, $F$. oxysporum and $F$. dimarium were obtained from Plant Pathology Research Institute, Agric. Res. Center (A.R.C.), Giza, Egypt.

Isolation and purification of Fungi

Ten grams of soil samples was suspended in 90 $\mathrm{ml}$ of sterile tap water and serial dilution were made. One $\mathrm{ml}$ from each dilution was transferred to Petridishes. Thereafter, potato dextrose agar (PDA) was added and mixed thoroughly. Three replicates were prepared from each dilution. Colony units were obtained after five days of incubation at $30^{\circ} \mathrm{C}$ and purified on PDA medium. The fungall isolates were maintained on PDA medium at $4^{0} \mathrm{C}$ for further use.

Antagonistic effect of the fungal isolates against pathogenic fungi:

This work was carried out to manage the causes damping-off diseases of sugar beet Fusarium spp. by applying bioagents. Six antagonistic fungi were screened for their efficiency in inhibiting the linear growth (LG) of the target fungi. PDA plates $(9 \mathrm{~cm}$ diam.) were inoculated peripherally with each of the 
pathogens and the bioagents under study at the opposite side to each other and incubated at $30^{\circ} \mathrm{C}$ for 7 days. After the elapse of the incubation period, the colony diameter of pathogens were measured and recorded as the percentage of reduction over the control. Three replicates plates were used. A complete randomized design was used in this experiment. The percentage of reduction $(\mathrm{R} \%)$ in the mycelial growth was calculated according to the following formula adopted by Ferreira et al. (1991) as follows:

$$
\mathbf{R} \%=\frac{A-B}{A} \times 100
$$

where

$\mathrm{R} \%=$ Percentage of growth reduction.

$\mathrm{A}=$ The distance of mycelial growth of the pathogenic fungi in the control.

$\mathrm{B}=$ The distance of mycelial growth of the pathogenic fungus towards the tested bioagents.

Identification of fungal isolates:

The best antagonistic fungal isolates were identified by microscopic observation according to (Domsch et al., 1993 and Samson et al., 2000) in the Regional Center for Mycology and Biotechnology Culture Collection on Identification Unit. Faculty of Science. Al-Azhar University, Cairo, Egypt.

In vivo pot experiments:

This experiment aims at investigate the role of isolate No. (2) and (3) were the most effective in vitro with pathogen fungi (Fusarium spp.) to control damping-off of sugar beet.

Pots $(35 \mathrm{~cm}$. in diameter) were sterilized by immersing in 5\% formalin solution for 10 mins. and left to dry in open air. Soils were sterilized by formalin. 4 $\mathrm{kg}$ of sterilized soil were put in each pot. Five mm mycelial disk from a 5 days old culture of Fusarium spp. grown on PDA were prepared by growing in sterilized glass bottles $(500 \mathrm{ml})$ containing $150 \mathrm{~g}$ sorghum seeds, $50 \mathrm{~g}$ clean sand, $4 \mathrm{~g}$ glucose and $200 \mathrm{ml}$ water and incubated at $27 \pm 1^{\circ} \mathrm{C}$ for 15 days.

Fungi surface sterilized seeds were soaked for one hour before sowing in a 5-day-old culture of Trichoderma spp. $\left(10^{8}-10^{9}\right.$ spores $\left./ \mathrm{ml}\right)$ grown in liquid potato dextrose broth medium. The supernatants were taken and used for seed treatment. Suspension was prepared by mixing of each bioagent with soaking $(2: 1 \mathrm{v} / \mathrm{w})$.

Ten seeds were sown in each pot and four replicates were used for each treatment. Surface sterilized un-soaked seeds were served as a control check.

Assessment of disease incidence was calculated as a percentage of pre- and post-emergence damping-off after 15 and 45 days of sowing. These experiments were carried out under greenhouse conditions for growing season 2014/2015.

Percentages of pre and post-emergence dampingoff as well as survival plants were calculated up to 45 days from planting as follows:

$1 . \%$ of pre-emergence damping-off $=$ (No. of nonemerged seeds/No. of sown seeds) x 100
2. $\%$ of post-emergence damping-off $=($ No. of killed seedlings/ total No. of emerged seedlings) x 100

3. $\%$ of survival plants $=($ No. of un-infected plants/total No. of plants) x 100

Antagonistic parameters produced by $T$. viride

Detection of Hydrogen Cyanide (HCN)

The production of hydrocyanic acid $(\mathrm{HCN})$ was tested according to Bakker and Schippers (1987). Tryptone soy agar containing $4.4 \mathrm{~g}$ per liter of glycine was prepared and inoculated with fungal cultures. Filter paper soaked in $0.5 \%$ picric acid solution and $2.0 \%$ sodium carbonate was placed inside the lid of the plate. Plates were incubated at $28{ }^{\circ} \mathrm{C}$ for 3 days inversely. Development of yellow to orange-brown color referred to $\mathrm{HCN}$ production.

\section{Determination of Indole Acetic Acid (IAA)}

The amounts of IAA were determined according to (Ehmann, 1977). The isolates were grown in yeast malt dextrose broth medium (YMD broth) and incubated at $28{ }^{\circ} \mathrm{C}$ for 4 days. After incubation, the broth was centrifuged. $50 \mu \mathrm{l}$ of $10 \mathrm{mM}$ orthophosphoric acid were prepared and a $2 \mathrm{ml}$ of Salkowski reagent consist of $1 \mathrm{ml}$ of $0.5 \mathrm{M} \mathrm{FeCl}_{3}$ in $50 \mathrm{ml}$ of $35 \% \mathrm{HClO}_{4}$ were prepared and added to the mixture. Development of a pink colour referred to the presence of indole acetic acid production.

\section{Cellulase production}

Yeast extract peptone agar medium were prepared. This medium consist of (yeast extract, $0.1 \mathrm{~g}$; peptone $0.5 \mathrm{~g}$; agar, $20 \mathrm{~g}$ and distilled water, $1000 \mathrm{~mL}$; $\mathrm{pH}$, 6.5) completed with $0.5 \%$ Na-carboxymethyl cellulose (CMC). After incubation, Congo Red was added to the plates. The colony that surroundded by clear zone refered to cellulase production. (Lingappa and Lockwood, 1962)

\section{Chitinase production}

Colloidal chitin was made according to Faramarzi et al., (2009). Chitinase detection medium was made according to Wirth and Wolf 1990.

\section{Statistical analysis}

The obtained data were subjected analysis of variance (ANOVA) (Steel and Terrie 1960). Least significant differences (L.S.D.) and Duncan's multiple range test (DMRT) were applied for comparing means under study (Duncan, 1955).

\section{RESULTS AND DISCUSSION}

\section{Isolation and purification of fungi}

After chosen, six fungal isolates were isolated and purified from different types of soil and were examined in this study to control damping-off of sugar beet

Antagonistic effect of fungal isolates against fungal pathogens in vitro

Data presented in Table (1) indicated that all bioagents actively affected the growth of the three pathogens under study and slight differences between them were observed. Isolate No.3 was the most potent inhibitors to the growth of $F$. solani compared to the other used fungi, followed by isolate No.2. The least effect was happened by the isolates No 5 and No. 6 . The 
rest antagonists distributed between these two extremists.

Results shown in Table (1) indicated that, isolates No. 3 reduced growth of $F$. oxysporum $(72.22 \%)$ more than No. 2 (71.44\%). Isolates No. 1 and No.4 have moderately effect in reducing the radial growth of $F$. oxysporum compared with the control. While isolates No. 5 and No. 6 were the least effective against the same fungus, it gave 34.11 and $49.22 \%$ reduction, respectively.

In the case of $F$. dimerum, as shown in Table (1), results showed that isolates No.3 and No. 2 were the most effective $(69.43 \%)$ and $(67.86 \%)$ respectively. While isolates No. 6 and No. 4 were the least effective against $F$. dimerum compared with the other bioagents.

Table 1. Effect of fungal isolates on the reduction ( $\mathrm{R} \%$ ) of linear growth $F$. solani, $F$. oxysporum and $F$. dimerum.

\begin{tabular}{|c|c|c|c|c|c|c|}
\hline \multirow[b]{2}{*}{$\begin{array}{l}\text { Fungal isolate } \\
\text { No. }\end{array}$} & \multicolumn{2}{|c|}{ F. solani } & \multicolumn{2}{|c|}{ F. oxysporum } & \multicolumn{2}{|c|}{ F. dimerum } \\
\hline & $\begin{array}{l}\text { L.G } \\
\text { "cm" }\end{array}$ & $\begin{array}{c}\text { Reduction } \\
\%\end{array}$ & $\begin{array}{l}\text { L.G } \\
\text { "cm" }\end{array}$ & $\begin{array}{c}\text { Reduction } \\
\%\end{array}$ & $\begin{array}{l}\text { L.G } \\
\text { "cm" }\end{array}$ & Reduction\% \\
\hline 1 & $4.10^{\mathrm{a}}$ & 54.09 & $4.17^{\mathrm{a}}$ & 53.67 & $4.37^{c}$ & 51.06 \\
\hline 2 & $2.23^{\mathrm{e}}$ & 75.03 & $2.57^{\mathrm{e}}$ & 71.44 & $2.73^{\mathrm{d}}$ & 69.43 \\
\hline 3 & $1.93^{\mathrm{t}}$ & 78.39 & $2.50^{\mathrm{e}}$ & 72.22 & $2.87^{\mathrm{d}}$ & 67.86 \\
\hline 4 & $4.33^{\mathrm{ca}}$ & 51.51 & $4.43^{\mathrm{c}}$ & 50.78 & $5.30^{\mathrm{D}}$ & 40.65 \\
\hline 5 & $6.23^{\mathrm{D}}$ & 30.24 & $5.93^{\mathrm{b}}$ & 34.11 & $4.07^{\mathrm{c}}$ & 54.42 \\
\hline 6 & $4.47^{\mathrm{c}}$ & 49.94 & $4.57^{\mathrm{c}}$ & 49.22 & $5.40^{\mathrm{b}}$ & 39.53 \\
\hline Control & $8.93^{\mathrm{a}}$ & 0.00 & $9.00^{\mathrm{a}}$ & 0.00 & $8.93^{\mathrm{a}}$ & 0.00 \\
\hline
\end{tabular}

Values with different letters are significantly different $\quad$ L.G: Linear growth of the pathogen $(\mathrm{cm})$

Identification of fungal strains:

Of the six fungal isolates, two were chosen for identification because they showed very high antagonism against Fusarium solani, F. oxysporum and
$F$. dimarium. These two fungal isolates No.(3) and No.(2) were identified as Trichoderma viride code No.(1) and Trichoderma viride code No.(2) according to source of soil samples. Table(2) and Photo (1).

Table 2. Microscopic and Culture examination for fungal isolates

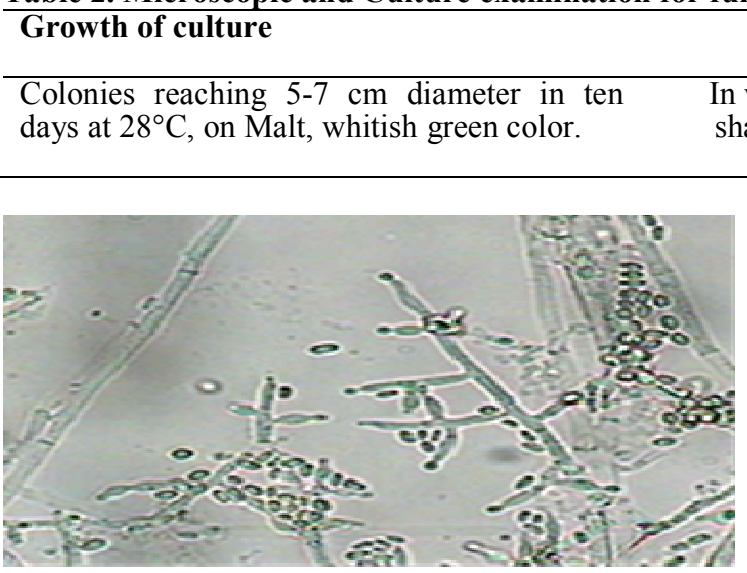

Photo 1. Microscopic observation of Trichoderma spp. using an image analysis system .

Effect of $T$. viride inoculation on damping-off and survival plants infected with Fusarium spp.

$T$. viride code No. (1) and T. viride code No. (2) were the most effective in vitro, so they were selected to test their antagonistic activity in the greenhouse. Data in Table (3) indicated that all treatments decreased damping-off and increased healthy plants compared with the control treatment. Afify and Ashour (1995) recommended that $T$. hrazianum bio-controlling agents as combination in integrated control system of dampingoff disease. Also, Tondje et al. (2007) reported that Trichoderma spp. has been widely used in biological control studies against several commercial phytopathogens.
Phialides Microscopic examinations n whorls of 2-4 flask shaped, $8.8 \times 2.5 \mu \mathrm{m}$.
Conidia

Conidia sub - spherical, green in mass $3.8 \times 2.0 \mu \mathrm{m}$.

a) Effect of $T$. viride isolates on damping-off and survival plants infected with $\boldsymbol{F}$. solani.

Data in Table (3) indicate that all treatments decreased damping-off and increased healthy plants compared with the control treatment. $T$. viride code No. (2) $(75 \%)$ was the most effective survival plants, followed by $T$. viride code No. (1) $(72.5 \%)$.

Table 3. Evaluation of the efficacy of $T$. viride isolates against $F$.solani in controlling damping- off of sugar beet seedling in the greenhouse

\begin{tabular}{|c|c|c|c|}
\hline \multirow[b]{2}{*}{ Treatments } & \multicolumn{2}{|c|}{$\begin{array}{c}\text { Damping - off } \\
(\%)\end{array}$} & \multirow[b]{2}{*}{$\begin{array}{c}\text { survival } \\
\text { plants } \\
(\%)\end{array}$} \\
\hline & ص & 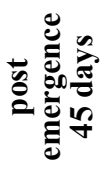 & \\
\hline $\begin{array}{l}\text { Trichoderma viride code No. } \\
(1) .+ \text { F.solani }\end{array}$ & $12.5^{\mathrm{b}}$ & $27.5^{b}$ & $72.5^{\mathrm{b}}$ \\
\hline $\begin{array}{l}\text { Trichoderma viride code No. } \\
\text { (2). }+ \text { F.solani }\end{array}$ & $12.5^{\mathrm{b}}$ & $25^{b}$ & $75^{\mathrm{a}}$ \\
\hline Un treated control( F.solani) & $35^{\mathrm{a}}$ & $55^{\mathrm{a}}$ & $45^{b}$ \\
\hline
\end{tabular}

Values with different letters are significantly different

Ushamalini et aI. (1997) studied the inhibitory effects of antagonists $T$. viride, $T$. hrazianum $T$. hamatum and T. koningii against $M$. phaseolina and $F$. 
spp. and they found that all the antagonists significantly inhibited the growth of $M$. phaseolina. $T$. viride and $T$. hrazianum were the most effective but in case of $F$. oxysporum. $T$. hrazianum was also, the most effective.

b) Effect of $T$. viride isolates on damping-off and survival plants inoculated with $T$. viride and infected with $F$. oxysporum.

While $F$ oxysporum, data in Table (4) indicated that $T$. viride code No. (2) $(75 \%)$ was the most effective survival plants, followed byT. viride code No. (1) $70 \%$ Gouda (2001) showed the possibility of controlling sugar beet damping-off and root rot by certain bioagants T. hamatum, T. harzianum, Pseudomonas and Bacillus subtilis under greenhouse and field condition, Trichoderma spp. and $P$. flurescense the most effective against all soil borne pathogens.

Table 4. Evaluation of the efficacy of $T$. viride isolates against F.oxysporum in controlling damping-off of sugar beet seedling in the greenhouse

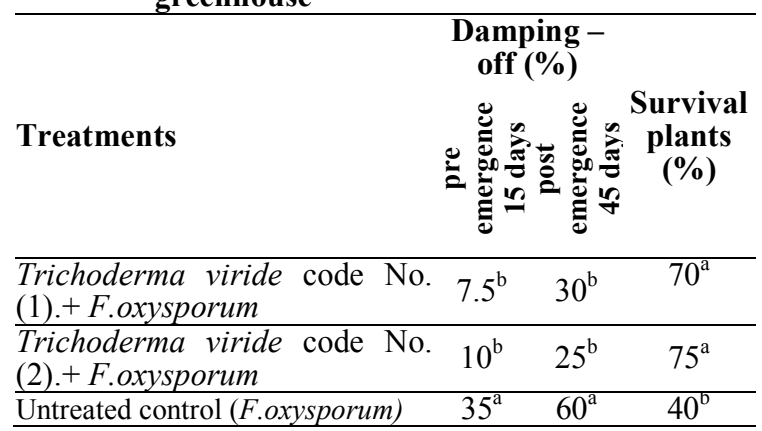

Values with different letters are significantly different

c) Effect of $T$. viride isolates on damping-off and survival plants inoculated with $T$. viride and infected with $F$. dimerum.

In the case of $F$. dimerum data in Table (5) indicated that $T$. viride code No. (2) was the most effective $(82.5 \%)$ survival plants followed by $T$. viride code No. (1) $70 \%$. Esh (2000) in vivo studies showed that high significant differences between the bioagents in controlling damping- off diseases in the greenhouse the highest effect showed by the bioagent $T$. hamatum followed by $T$. viride.

Table 5. Evaluation of the efficacy of $T$. viride isolates against F.dimerum in controlling damping- off of sugar beet seedling in the greenhouse

\begin{tabular}{|c|c|c|c|}
\hline \multirow[b]{2}{*}{ Treatments } & \multicolumn{2}{|c|}{$\begin{array}{c}\text { Damping - off } \\
(\%)\end{array}$} & \multirow[b]{2}{*}{$\begin{array}{c}\text { survival } \\
\text { plants } \\
(\%)\end{array}$} \\
\hline & 离 & 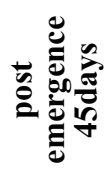 & \\
\hline $\begin{array}{l}\text { Trichoderma viride code } \\
\text { No. (1). }+ \text { F.dimerum }\end{array}$ & $10^{\mathrm{b}}$ & $30^{\mathrm{b}}$ & $70^{\mathrm{b}}$ \\
\hline $\begin{array}{l}\text { Trichoderma viride code } \\
\text { No. (2). }+ \text { F.dimerum }\end{array}$ & $5^{\mathrm{b}}$ & $17.5^{\mathrm{c}}$ & $82.5^{\mathrm{a}}$ \\
\hline Un treated control F.dimerum & $35^{\mathrm{a}}$ & $52.5^{\mathrm{a}}$ & $47.5^{\mathrm{c}}$ \\
\hline
\end{tabular}

Values with different letters are significantly different
Mechanism of biocontrol $T$. viride against Fusarium spp.

The Mechanism of antagonist of the two $T$. viride isolates was investigated. Results presented in Table (6) showed that T.viride code No. (1) and T. viride code No. (2) were all positive for HCN. T.viride code No. (1) and T.viride code No. (2) were all negative for IAA, while both $T$. viride code No. (1) and code No. (2) were produced cellulase and chitinase.Similar results were reported by Allpress et al., 2002. The production of hydrolytic enzymes has been described for the biocontrol activity (Sidhu and Dadarwal 2001).

Hoyos-Carvajal et al., (2009) showed that Trichoderma spp. establishes a benefical interaction within roots and have a similar result with symbioses to enhance crops growth and health. Zheng and Shetty (2000) reported that Trichoderma species improve seedling vigor and increase root length, thus helping host plants absorb more nutrients (Altomare et al., 1999). Hydrogen cyanide is a microbial metabolite that promotes plant nitrogen accumulation and root elongation (Marques et al., 2010).

Table 6. Production of some antagonistic properties by $T$. viride isolates:

\begin{tabular}{llc}
\hline $\begin{array}{l}\text { Fungal } \\
\text { isolates }\end{array}$ & HCNIAA & $\begin{array}{c}\text { Enzymes } \\
\text { production }\end{array}$
\end{tabular}

$\begin{array}{llll} & & \text { Cellulase Chitinase } \\ \text { T. viride code No. (1) } & + & - & +\end{array}$

T. viride code No. (2). $+\quad+\quad-\quad+\quad+\quad+$

Finally, this shows that $T$. viride are quite important and effective as biocontrol agents.

\section{REFERENCES}

Afify, Aida, H. and Ashour, A.Z.A. (1995). Biological and chemical control on cotton.J. Agric. Sci. Mansoura Univ., 20 (4):1441-1452

Allpress, J.D.; Mountain, G. and Gowland, P.C. (2002). Production, purification and characterization of an extracellular keratinase from Lysobacter NCIMB 9494. Lett. Appl. Microbiol., 34: 337-342.

Altomare, C.; Norvell, W.A.; Bjorkman, T. and Harman, G.E. (1999). Solubilization of phosphates and micronutrients by the plant-growth-promoting and biocontrol fungus Trichoderma harzianum . Appl. Environ. Microbiol., 65:2926-2933

Bakker, A.W. and Schippers, B. (1987). Microbial cyanide production in the rhizosphere in relation to potato yield reduction and Pseudomonas spp. mediated plant growth stimulation. Soil Biol. Biochem., 19:451-457

Chet, I. and Baker, R. (1981). Isolation and biocontrol potential of Trichoderma hamatum from soil naturally suppressive to Rhizoctonia solani. Phytopathol., 286-290

Cook, R.J. and Baker, K.F. (1983). The Nature and Practice of Biological Control of Plant Pathogens. American Phytopathol. Soc. USA: 539.

Domsch, K.H.; Gams, W. and Anderson, T.H. (1993).Compendium Of Soil Fungi.

Duncan, D.B. (1955). Multible range and multible F-tes. Biometrics. 11:1-42. 
Ehmann, A. (1977). The Van Urk-Salkowski reagent-a sensitive and specific chromogenic reagent for silica gel thin-layer chromatographic detection and identification of indole derivatives. J. of Chromatography. 132, 267-276.

El-Kholi, M.M.A. (2000). Sugar beet diseases in Egypt. The Ninth Conf. of Phytopathol..The Egypt Phytopathol. Soc., Giza, Egypt

Esh, A.M.H.E. (2000). Studies on some sugar beet root disease in Egypt. Ph.D. Thesis, Fac. Agric., Zagazig Univ., $287 \mathrm{pp}$

Etesami, H.; Alikhani, H.A.; Jadidi, M. and Aliakbari, A. (2009). Effect of superior IAA producing rhizobia on $\mathrm{N}, \mathrm{P}, \mathrm{K}$ uptake by wheat grown under greenhouse condition. World. J. Appl Sci., 6: 16291633.

Faramarzi, M.A.; Fazeli, M.; Yazdi, M.T.; Adrangi, S.; AlAhmadi, K.J.; Tasharrofi, N. and Mohseni, F.A. (2009). Optimization of Cultural Condition for Production Chitinase by Soil Isolate of Massilia timonae. Biotechnol.., 8, 93-99.

Ferreira, J.H.S.; Mathee, F.N. and Thomas, A.C. (1991). Biological control of Eutypta lota on grapevine by an antagonistic strain of Bacillus subtilis. Phytopathol., 81: 283-287.

Gouda, M.I.M. (2001). Studies on some sugar beet root diseases. Ph. D. thesis, Fac. Agric. KafrEl-shiekh Univ. Phytopathol. 94:1259-1266

Howell, C.R. (2003). Mechanisms employed by Trichoderma species in the biological control of plant diseases: the history and evolution of current Concepts. Plant Dis., 87: 4-10.

Hoyos-Carvajal, L.; Orduz, S. and Bissett, J. (2009). Growth stimulation in bean (Phaseolus vulgaris L.) by Trichoderma. Biocontrol 51:409-416

Kidoglu, F.; Gül, A. and Ozaktan, H. Y.T. (2007). Effect of rhizobacteria on plant growth of different vegetables. Acta Hortic (ISHS), 801: 1471-1478.

Lingappa, Y. and Lockwood, J.L. (1962). Chitin media for selective isolation and culture of actinomycetes. Phytopathol., 52: 317-323.

Marques, A.P.G.C.; Pires, C.; Moreira, H.; Rangel, A.O.S.S. and Castro, P.M.L. (2010). Assessment of the plant growth promotion abilities of six bacterial isolates using Zea mays as indicator plant. Soil Biol. Biochem., 42:1229-1235
Mosa, A.A. and El-Kholi, M.M. (1996). Characterization and pathogenicicity of anastomosis groups of Rhizoctonia solani isolated from sugar beet in Egypt. J. Agric. Res., 75(3): 717-729.

O'Sullivan, D. J. and O'Gara, F. (1992). Traits of fluorescent Pseudomonas spp. involved in suppression of plant root pathogens. Microbiol. Rev.; 56- 662-76.

Samson, R.A; Hoekstra, E.S. and Frisvad, J.C. (2000).Introduction To Food- And Airborne Fungi.

Sindhu, S.S. and Dadarwal, K. B. (2001). Chitinolytic and cellolytic Pseudomonas spp. antagonistic to fungal pathogens enhances nodulation by Mesorhizobium spp. Cicer in chickpea. Microbiol. Res.; 156: 353-8.

Steel, P.G.D. and Torrie, J.H. (1960). Principle and procedures of statistics. MCG raw, Hill Book Co.Inc. New York, 481pp.

Tondje, R.R.; Roberts, D.P.; Bon, M.C., Widmer, T.; Samuels, G.J.; Ismaiel, A.; Begoude, A.D.; Tchana, T.; Nyemp-Tshomb, E.; Ndoumbenkeng M.; Bateman, R., Fontem, D. and Hebbar, K.P. (2007). Isolation and identification of mycoparasitic isolates of Trichoderma asperellum with potential for suppression of black pod disease of cacao in Cameroon. Biological Control. 43:202-212.

Ushamalini, C.; Rajappan, K. and Gangadharan, K. (1997). Inhibtion of Macrophomina phaseolina and Fusarium oxysporum f.sp.tracheiphilum by antagonists under in vitro condition plant. Dis. Res., 12:168-170.

Wirth, S.J. and Wolf, G.A. (1990). Dye-labeled substrates for the assay and detection of chitinase and lysozyme activity. J. Microbiol Methods.12:197205.

Yadav, J.; Verma, J.P. and Tiwari, K.N. (2011). Plant Growth Promoting Activities of Fungi and Their Effect on Chickpea Plant Growth. Asian J. of Biol. Sci. 4: 291-299.

Zheng, Z.X. and Shetty, K. (2000) .Enhancement of pea (Pisum sativum) seedling vigour and associated phenolic content by extracts of apple pomace fermented with Trichoderma spp. Process Biochem., 36:79-84

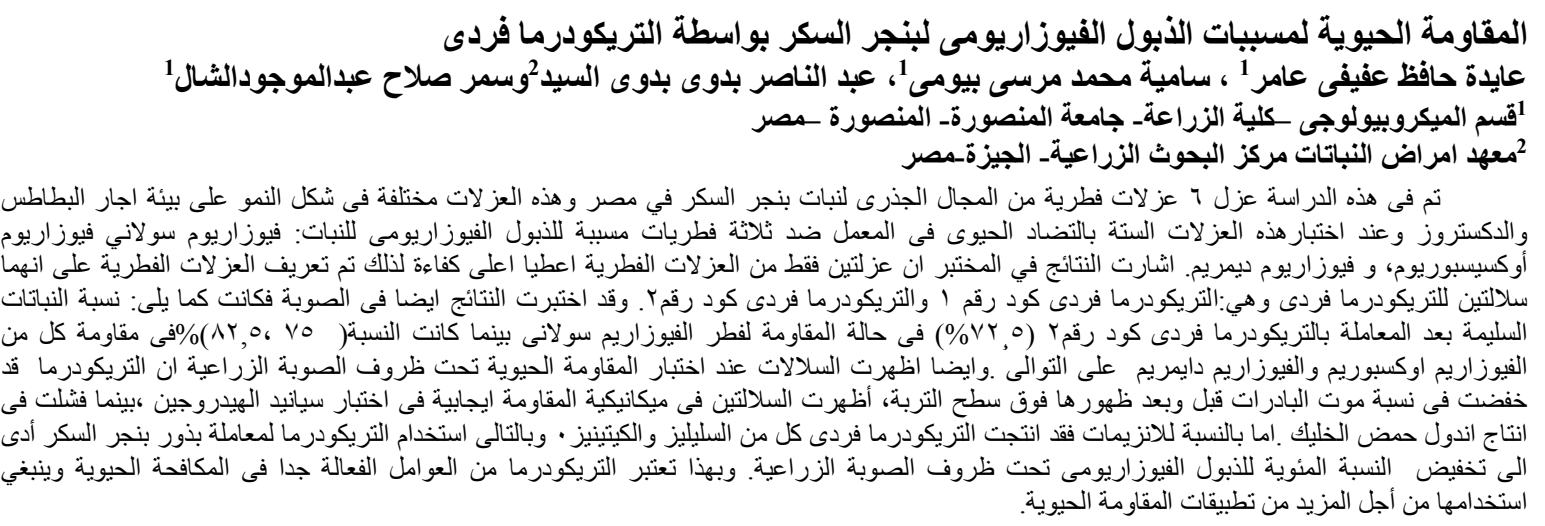

